Teka Kom. Hist. OL PAN-TN KUL, 2020, 2(17), 135-142

DOI: http://dx.doi.org/10.18290/teka.20.7

\title{
KAPUCYNI POLSCY A WYDARZENIA 1920 ROKU
}

\author{
Roland Prejs OFMCap \\ Katolicki Uniwersytet Lubelski Jana Pawła II \\ Katedra Historii Kościoła w Czasach Nowożytnych i Dziejów Teologii \\ The John Paul II Catholic University of Lublin \\ Department of Church History in Modern Times and History of Theology \\ e-mail: rolandsberg@op.pl
}

\begin{abstract}
Streszczenie. Do wydarzeń rozgrywających się na ziemiach polskich w 1920 r. kapucyni nie odnieśli się obojętnie, ale z powodu poważnych braków personalnych i konieczności zapewnienia bieżącej obsługi duszpasterskiej kościołów klasztornych nie mogli zaangażować się na większą skalę. Największą aktywność przejawił Wiator Rytel, który był kapelanem szpitali wojskowych, ponadto organizował wśród tercjarzy szycie bielizny dla wojska, a także zbieranie różnych ofiar i składek, za które między innymi zakupiono i wyposażono pociąg sanitarny.
\end{abstract}

Słowa kluczowe: Polska; kapucyni; 1920 rok.

Określenie ,wydarzenia 1920 roku” zawarte w tytule artykułu oznacza to wszystko, co działo się na ziemiach polskich w 1920 r., lub pozostawało w ścisłym związku z ówczesnymi wydarzeniami dotyczącymi odradzającego się niepodległego państwa polskiego. W szczególności będą to: wyprawa wojsk polskich na dawne Kresy Wschodnie, inwazja bolszewików, wreszcie odparcie bolszewików przez wojsko polskie w sierpniu 1920 r., co później nazwano „cudem nad Wisłą”.

1 Pomijamy w tym miejscu szersze omówienie postawy Episkopatu Polski wobec wydarzeń 1920 r. Zagadnienie to było już poruszane w literaturze. Zob.: Kościót w czasie wojny polsko-bolszewickiej 1919-1920. Antologia tekstów historycznych i literackich, oprac. M.M. Drozdowski, A. Serafin, Warszawa 1995; M.B. MARKowski, Polskie duchowieństwo rzymskokatolickie wobec wojny z Rosja bolszewicka w latach 1919-1920, w: Duchowieństwo polskie w latach niepodległości 1918-1939 $i$ w okresie II wojny światowej, red. J. Gapys, M.B. Markowski, Kielce 2006, s. 23-40. Brakuje opracowań dotyczących zagadnienia udziału zakonów i zgromadzeń zakonnych w tych wydarzeniach. Warto zatem wskazać opracowanie M. Sadowskiego, Redemptoryści na drogach polskiej niepodległości, „Studia Redemptorystowskie”, 16 (1918), s. 253-254. 
Bezpośrednio po odzyskaniu przez Polskę niepodległości kapucyni na ziemiach polskich byli zorganizowani w dwie jednostki: prowincję polską, w skład której wchodziły klasztory w Łomży, Nowym Mieście nad Pilicą, Warszawie (odzyskany z początkiem 1918 r.) i Lublinie (odzyskany w połowie 1919 r.) oraz komisariat galicyjski, w skład którego wchodziły klasztory w Krakowie, Krośnie, Kutkorzu, Olesku, Rozwadowie, Sędziszowie i Zamarstynowie, przy czym ta ostatnia miejscowość niezadługo została włączona administracyjnie do Lwowa. Według ówczesnych konstytucji zakonnych jednostka, w której nie było przynajmniej 50 kapłanów, nie stanowiła samodzielnej prowincji, lecz tylko tzw. komisariat, a więc strukturę, w której nie odbywały się kapituły, a przełożony wyższy (komisarz prowincjalny, zamiast prowincjała) nie pochodził z wyboru współbraci, lecz z nominacji generała zakonu. Formalnie rzecz biorąc, również prowincja polska powinna być komisariatem - było w niej tylko kilkunastu zakonników, którzy przeżyli carską kasatę klasztorów w 1864 r., lub zostali przyjęci do zakonu po 1905 r. (tzw. ukaz tolerancyjny), ale wskutek carskich restrykcji nie mogła odbyć się wizytacja generała lub jego delegata, który zredukowałby prowincję do rangi komisariatu. Wprawdzie w $1917 \mathrm{r}$. klasztor w Nowym Mieście zwizytował definitor generalny Zenon Aicher, ale uznał, że czas wojny nie jest dogodną porą do wprowadzania tego rodzaju zmian i odłożył je do stosowniejszej okazji. Ponadto wśród niektórych zakonników żywe było pragnienie połączenia prowincji polskiej i komisariatu galicyjskiego $\mathrm{w}$ jedną jednostkę, ale stosowne decyzje generał zakonu mógł podjąć także po przeprowadzeniu stosownej wizytacji, na której z autopsji poznałby stan faktyczny. Zrozumiałe zatem, że zakonnicy oczekiwali przede wszystkim wizytacji generalnej, na której - jak spodziewali się - zapadną stosowne decyzje co do przyszłości²

\section{WOJNA POLSKO-BOLSZEWICKA}

W 1914 r. na kapelana Legionów Piłsudskiego został powołany o. Kosma Lenczowski (1881-1959) z komisariatu krakowskiego. Wyruszył 8 sierpnia 1914 r. na front, w latach 1914-1815 brał udział w bitwach, a w 1917 r. został kapelanem Czwartego Pułku Piechoty w Zegrzu. Ponieważ w 1918 r., po zawarciu pokoju brzeskiego pułk złożył broń, legioniści zostali internowani, a wraz z nimi kapelan,

2 Zagadnienia te omawiają: J. Marecki, Dzieje Zakonu Kapucynów w okresie II Rzeczypospolitej, Kraków 2000, passim; F.J. Duchniewski, Z dziejów Polskiej Prowincji Kapucynów (1810-1921), w: W stużbie pokoju i dobra. Jubileusz pięćdziesięciolecia odrodzenia Warszawskiej Prowincji Kapucynów. Księga pamiątkowa, red. R. Prejs, Warszawa 2002, s. 25-67. 
który pozostawał w obozie internowanych do 24 kwietnia 1918 r., czyli do chwili likwidacji obozu. Jeszcze w 1918 r. Lenczowski wrócił do klasztoru w Krakowie jako zdemobilizowany ${ }^{3}$.

Może dziwić, że Lenczowski, doświadczony kapelan wojskowy, był nieobecny w wojnie polsko-bolszewickiej w 1920 r. Stanie się to zrozumiałe po lekturze pamiętnika spisanego przez kapelana Legionów ${ }^{4}$. Lenczowski przez cztery lata służby kapelańskiej poznał wojsko z bliska, zarówno od dobrej jak i od złej strony. O ile miał dobre zdanie o szeregowych żołnierzach, o tyle wobec oficerów był znacznie bardziej krytyczny: zarzucał im powierzchowną religijność, a często niewiarę, bezideowość, niemoralne życie, czy pięcie się po szczeblach kariery. Nawet zakładając, że był to sąd przynajmniej miejscami przerysowany, nie sposób nie zauważyć, że Lenczowski chyba nie pragnął powrotu do wojska. Jego postawa stanie się bardziej zrozumiała w świetle zapisów kronikarza klasztoru krakowskiego.

Nie dochowały się do naszych czasów kroniki klasztorów w Warszawie i Łomży: pierwsza spaliła się w czasie powstania warszawskiego w 1944 r., drugiej prawdopodobnie nie prowadzono w 1920 r. - założono ją w następnych latach. Zachowała się natomiast kronika klasztoru w Krakowie. Kronikarz dość cierpko wyraził się o działaniach wojsk polskich w 1920 r.: był zdania, że wprawdzie rzeczywiście ziemie te przed rozbiorami należały do Polski, a na wschodnich rubieżach mieszkało wielu Polaków i należało przyjść im z pomocą, ale z militarnego punktu widzenia wyprawa Piłsudskiego na Kijów była nieroztropnością i wciągnęła odradzającą się Rzeczpospolitą w wojnę z Rosją sowiecką. Trudno odpowiedzieć, w jakim stopniu kronikarz wyrażał własne poglądy, w jakim zaś powtarzał opinie krążące wówczas w środowisku krakowskim, pozostaje faktem, że w krakowskim klasztorze Kapucynów postawa wobec wojny polsko-bolszewickiej była nacechowana rezerwą5.

Nie znaczy to, że krakowscy kapucyni odnieśli się wrogo do walki w obronie zagrożonej niepodległości. Kronikarz zapisał, że w sierpniu 1920 r. o. Anioł Madejewski na prośbę dowództwa garnizonu krakowskiego podjął się głoszenia nauk o treści religijno-patriotycznej dla formujących się oddziałów wojskowych. Miewał je przez kilka miesięcy w każdy wtorek ${ }^{6}$. Nie odnajdujemy wzmianki, czy zakonnik głosił te nauki w koszarach, czy rekruci przychodzili na nie do kościoła klasztornego. Wydaje się wszakże, że przybywali do kościoła, na co wskazywałaby inna wzmianka w kronice, mianowicie, że kapucyni spowiadali zmobilizowanych

\footnotetext{
3 Dane biograficzne: J.L. GAdACZ, Stownik polskich kapucynów, t. I, Wrocław 1985, s. 673-675.

4 K. Lenczowski, Pamiętnik kapelana Legionów, oprac. J.T. Nowak, Kraków-Krosno 1989.

5 Archiwum Krakowskiej Prowincji Kapucynów [dalej: ArKapKr], sygn. AKK 100, s. 159.

6 Tamże, s. 160.
} 
żołnierzy przed wymarszem na front. Kronikarz zaznaczył, że tych spowiedzi było bardzo dużo, nie podał jednak, ilu zakonników było zaangażowanych w tę posługę i ile czasu ona zajęła ${ }^{7}$.

Kapucyni poważnie liczyli się z tym, że wojska bolszewickie mogą wejść do Krakowa. Świadczy o tym fakt, że stosowne zapisy w kronice sporządzono dopiero przy końcu roku; bieżące notatki są treści czysto obojętnej - mówią o odpustach, na których kapucyni głosili kazania lub odprawiali uroczyste nabożeństwa, wspominają o dokonujących się obłóczynach nowicjuszy lub o składaniu ślubów, ale czytając te zapiski można odnieść wrażenie, jakoby kronikarz świadomie nie chciał pisać wszystkiego ${ }^{8}$. Dopiero kiedy niebezpieczeństwo bolszewickie ustało, pozwolił sobie na większą szczerość.

Inny kapelan Legionów, o. Damian Węgiel, w tym czasie zdradzał już wyraźnie objawy choroby nerwowej. Zakonnik jeszcze w 1915 r. opuścił wojsko, a ściślej: otrzymał dymisję wskutek nader krytycznego podejścia do relacji pomiędzy Legionami a armią austriacką. Ponadto niefortunny kapelan miał prowadzić wśród żołnierzy agitację, że walka o niepodległość Polski nie ma szans powodzenia. Zrozumiałe, że w 1920 r. nikt go w tej sytuacji nie powoływał do posługi kapelańskiej, mimo że zakonnik posiadał stopień majora. W niedługim czasie okazało się, że wymaga raczej intensywnego leczenia i przebywania w warunkach zapewniających spokój, a nie wojenne emocje, co ostatecznie w 1933 r. stało się przyczyną, że zakonnik opuścił Polskę i osiadł we Włoszech? 9

\section{DZIAŁALNOŚĆ O. WIATORA RYTLA I WARSZAWSKICH TERCJARZY}

W wydarzenia 1920 r. włączył się na wiele sposobów o. Wiator Rytel. Zakonnik przebywał w tym czasie w klasztorze w Warszawie, do którego przybył z początkiem 1919 r. Niezbędne wydaje się nakreślenie, choćby w skrócie, jego biografii. Pochodził z Mojówki na Podolu, gdzie urodził się 28 lipca 1883, na chrzcie otrzymał imię Wacław, był synem Cezarego i Józefy z Jachimowiczów. W latach 19011904 studiował w seminarium duchownym w Petersburgu, skąd został usunięty, podobno za jakieś kontakty z socjalistami. Ponieważ jednak otrzymał od władz se-

\footnotetext{
7 Tamże, s. 168.

8 Tamże, s. 162-164.

9 J.L. GADACZ, Stownik, t. II, s. 405-410. O przebiegu służby kapelańskiej pisze K. GADACZ, Kapelańska epopeja. O. Kosma Lenczowski kapucyn, Asyż 1969, s. 130-133.
} 
minaryjnych dobre świadectwo moralności, wstąpił w 1907 r. do kapucynów w Nowym Mieście, otrzymując imię zakonne Wiator. Studia teologiczne odbył w seminarium duchownym we Włocławku, a święcenia kapłańskie przyjął 21 lipca 1912 r. Wkrótce objął redakcję miesięcznika dla tercjarzy „Rodzina Seraficka”. W czasie I wojny światowej oskarżony przez Rosjan o zdradę stanu, został uwięziony, a następnie sądzony w Witebsku. Sąd go wprawdzie uniewinnił, ale rozwój działań wojennych sprawił, że nie mógł wrócić do Nowego Miasta. Pozostał w Rosji jako duszpasterz środowisk polskich, z bliska jednak zobaczył, czym jest rewolucja bolszewicka. Do Polski powrócił w grudniu 1918 r. i zamieszkał w klasztorze w Warszawie. W 1920 r. zgłosił się na kapelana wojskowego, ale nie został wysłany na front, gdyż dowództwo wojskowe zleciło mu funkcję kapelana wojskowych szpitali warszawskich. Zaangażował się wówczas w działalność Towarzystwa „Pomoc Żołnierzowi Frontu", któremu przewodniczył. Zadaniem Towarzystwa było zbieranie funduszy na zakup uzbrojenia, umundurowania, leków i środków opatrunkowych dla wojska oraz wieloraka pomoc dla żołnierzy, którzy - zwłaszcza z powodu trwałego inwalidztwa - zostawali zdemobilizowani, a często nie mogli znaleźć sobie pracy, utrzymania i środków do życia. Już po zakończeniu działań wojennych za działalność w Towarzystwie Rytel otrzymał 15 lipca 1921 r. odznakę i dyplom Obywatelskiego Komitetu Obrony Państwa. Po wybuchu II wojny światowej został aresztowany przez Niemców i po krótkim pobycie na Zamku Lubelskim wywieziono go 20 czerwca 1940 do Sachsenhausen, a 14 grudnia 1940 do Dachau (nr obozowy 22.690). Tam zginął w komorze gazowej 12 sierpnia 1942 r. $^{10}$

W czasie pobytu w klasztorze w Warszawie Rytel zajmował się przede wszystkim krzewieniem i asystencją duchową Trzeciego Zakonu Franciszkańskiego (tercjarstwa), dla którego z początkiem 1920 r. reaktywował miesięcznik „Rodzina Seraficka”. Prawdopodobnie jego wpływ sprawił, że warszawska kongregacja tercjarska aktywnie włączyła się w działalność na rzecz wojska polskiego w 1920 r., zwłaszcza w czasie kampanii bolszewickiej. Jednym z przejawów tej działalności było szycie bielizny dla wojska ${ }^{11}$. Zachowane informacje nie podają, ile tej bielizny uszyto, ani na rzecz jakich oddziałów prowadzono tę akcję. Innym sposobem było zbieranie

${ }^{10}$ Postać o. Wiatora Rytla nie doczekała się monografii. Biogramy jego znajdują się w encyklopediach i leksykonach. Zob.: J.L. Gadacz, Stownik, t. II, s. 248-254; R. Prejs, Rytel Wacław, w: Polski słownik biograficzny, t. XXXIII, Wrocław 1992, s. 579-580; J. DuchniewsKi, Rytel Wacław Wiator, w: Stownik biograficzny katolicyzmu społecznego w Polsce, red. R. Bender, t. III, Lublin 1995, s. 42-43; R. Press, Piśmiennictwo religijne kapucynów Prowincji Polskiej na przelomie XIX i XX wieku, w: Kościól w Polsce. Dzieje i kultura, red. J. Walkusz, t. I, Lublin 2002, s. 137-155; TENŻE, Z dziejów pewnej ksiażki dla tercjarzy, „Pietas et Studium”, 2 (2009), s. 633-640.

${ }^{11}$ „Rodzina Seraficka”, 6 (1920), s. 283-288. 
ofiar i składek na rzecz dozbrojenia wojska lub na pomoc dla zdemobilizowanych żołnierzy. Już w lipcu 1920 r. redakcja „Rodziny Serafickiej” przekazała na ten cel 1.045 marek $^{12}$. W sierpniu zebrano 827 marek, ponadto 3.260 marek na Czerwony Krzyż, w październiku 620,50 marek, ponadto 3.130 marek na Czerwony Krzyż, wreszcie w listopadzie zebrano 220 marek, ponadto 220 marek na Czerwony Krzyż ${ }^{13}$. Zmieniająca się wartość pieniądza nie pozwala określić, jaka była realna wartość nabywcza pozyskanych w ten sposób pieniędzy, musiały wszakże być składane jeszcze inne ofiary i to niemałe, skoro Towarzystwo „Pomoc Żołnierzowi Frontu" zorganizowało i wyekwipowało dla wojska polskiego pociąg sanitarny, składający się z 20 wagonów, celem przewożenia rannych i chorych z frontu do

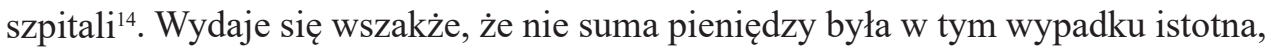
lecz budzenie w ten sposób świadomości, że wszyscy, a nie tylko rząd i wojsko, są odpowiedzialni za losy ojczyzny i mają na jej rzecz ponosić ofiary.

Wsparciem powyższych akcji była oczywiście modlitwa. Nocą z 29 na 30 lipca 1920 r. w warszawskim kościele Kapucynów odbyła się całonocna adoracja Najświętszego Sakramentu w intencji ocalenia ojczyzny. Spotkała się z dużą frekwencją ze strony warszawskiej kongregacji tercjarskiej ${ }^{15}$.

Na łamach redagowanej przez Rytla „Rodziny Serafickiej” ukazał się jeden tekst publicystyczny, sygnowany przez redaktora, a poświęcony wojnie polsko-bolszewickiej. Pisany nieco ,ezopowym” językiem, wytykał rządom polskim niezgodę i waśnie, wskazując, że one stały się przyczyną nieszczęścia: wróg napadł na kraj słaby i wewnętrznie skłócony. Gdyby Polska - zdaniem o. Wiatora Rytla - budowała swój byt na podstawie wartości chrześcijańskich, zgody narodowej i szukania wspólnego dobra, byłaby mocna, a żaden wróg nie odważyłby się jej zaatakować ${ }^{16}$.

Dodajmy jeszcze, że anonimowy autor, ukrywający się pod kryptonimem A. M-ski, nawoływał między innymi, aby wspomagać walczącą ojczyznę w ten sposób, że otoczy się opieką tych, którzy wskutek najazdu bolszewickiego byli zmuszeni opuścić swoje domy lub utracili mienie, ponadto aby przeciwdziałać agitacji komunistycznej, zwłaszcza na wsi, wreszcie aby zgłaszać się ochotniczo do służby sanitarnej w wojsku. Trudno odpowiedzieć, z jakim odzewem spotkały się te wezwania

\footnotetext{
12 Tamże, s. 224.

${ }^{13}$ Tamże, s. 224, 320, 352.

${ }^{14}$ [W. Rytel] Viator a MojówKa, Spraw, by żotnierz byt rycerzem Maryi, „Rodzina Seraficka”, 6 (1920), s. 289-292.

15 Tamże, s. 283-288.

${ }^{16}$ [W. Rytel] Viator a Mojówka, Boskie Serce Jezusa ratuj Ojczyznę nasza, „Rodzina Seraficka”, 6 (1920), s. 227-229.
} 
wśród czytelników miesięcznika ${ }^{17}$. Już po odparciu wojsk bolszewickich ukazały się artykuły o ks. Ignacym Skorupce ${ }^{18}$ czy o wsparciu Polski ze strony papieża Benedykta $\mathrm{XV}^{19}$.

O. Wiator Rytel był jedynym kapucynem komisariatu warszawskiego, który w wydarzenia 1920 r. zaangażował się na taką skalę. Dlaczego inni zakonnicy nie przejawili podobnej aktywności? Wytłumaczyć to trzeba sytuacją, w jakiej zakon znajdował się w tym czasie na ziemiach polskich. Większość zakonników to byli ludzie starsi, szeregi kapucynów w Polsce były w tym czasie dość przerzedzone, zwłaszcza wskutek antyzakonnej polityki zaborców, a młodsi musieli z konieczności zająć się bieżącą pracą duszpasterską w kościołach klasztornych przy niewielkiej obsadzie personalnej ${ }^{20}$. Na inne formy zaangażowania nie starczyło już ludzi i możliwości.

Gdyby patrzeć na zaangażowanie kapucynów w wydarzenia 1920 r. przez pryzmat statystyki, będzie ono rzeczywiście niewielkie. Musimy jednak mieć na uwadze sytuację organizacyjną i personalną zakonu w Polsce, o czym wyżej wspomnieliśmy. Rzeczywistego wpływu choćby takich akcji, jak szycie bielizny dla żołnierzy, czy organizowanie zbiórek pieniężnych nie da się wyliczyć i opisać - musimy poprzestać na stwierdzeniu, że i taka działalność była potrzebna oraz miała swoje znaczenie.

\section{BIBLIOGRAFIA}

Archiwum Krakowskiej Prowincji Kapucynów, sygn. AKK 100.

Duchniewski F.J., Z dziejów Polskiej Prowincji Kapucynów (1810-1921), w: W stużbie pokoju i dobra. Jubileusz pięćdziesięciolecia odrodzenia Warszawskiej Prowincji Kapucynów. Księga pamiątkowa, red. R. Prejs, Warszawa 2002, s. 25-67.

Duchniewski J., Rytel Wacław Wiator, w: Stownik biograficzny katolicyzmu społecznego w Polsce, red. R. Bender, t. III, Lublin 1995, s. 42-43.

\footnotetext{
${ }^{17}$ A. M-ski, Módlmy się za Polskę, ratujmy Ojczyznę nasza, „,Rodzina Seraficka”, 6 (1920), s. 259-261.

${ }^{18}$ [W. Rytel] Viator, Bohater kapłan - tercjarz, „Rodzina Seraficka”, 6 (1920), s. 272-274.

${ }^{19}$ Ojciec Święty o Polsce, ,Rodzina Seraficka”, 6 (1920), s. 258-259.

${ }^{20}$ Statystykę podaje J.L. GADACZ, Stownik, t. I, s. 140-142. W 1920 r. w prowincji polskiej (komisariacie warszawskim) w czterech klasztorach było ośmiu kapłanów, jeden kleryk i szesnastu braci zakonnych (razem 25 zakonników). W prowincji galicyjskiej (komisariacie krakowskim) w siedmiu klasztorach było 33 kapłanów, dwóch kleryków i 24 braci zakonnych (razem 59 zakonników).
} 
GADACZ J.L., Stownik polskich kapucynów, t. I-II, Wrocław 1985-1986.

GaDACz K., Kapelańska epopeja. O. Kosma Lenczowski kapucyn, Asyż 1969.

Kościót w czasie wojny polsko-bolszewickiej 1919-1920. Antologia tekstów historycznych i literackich, oprac. M.M. Drozdowski, A. Serafin, Warszawa 1995.

Lenczowski K., Pamiętnik kapelana Legionów, oprac. J.T. Nowak, Kraków-Krosno 1989.

Marecki J., Dzieje Zakonu Kapucynów w okresie II Rzeczypospolitej, Kraków 2000.

Markowski M.B., Polskie duchowieństwo rzymskokatolickie wobec wojny z Rosją bolszewicka w latach 1919-1920, w: Duchowieństwo polskie w latach niepodległości 1918-1939 i w okresie II wojny światowej, red. J. Gapys, M.B. Markowski, Kielce 2006, s. 23-40.

M-ski A., Módlmy się za Polskę, ratujmy Ojczyznę naszą, „Rodzina Seraficka”, 6 (1920), s. 259-261.

Ojciec Święty o Polsce, „Rodzina Seraficka”, 6 (1920), s. 258-259.

Press R., Piśmiennictwo religijne kapucynów Prowincji Polskiej na przełomie XIX i XX wieku, w: Kościół w Polsce. Dzieje i kultura, red. J. Walkusz, t. I, Lublin 2002, s. 137-155.

Prejs R., Rytel Wacław, w: Polski stownik biograficzny, t. XXXIII, Wrocław 1992, s. 579-580.

Prejs R., Z dziejów pewnej książki dla tercjarzy, „Pietas et Studium”, 2 (2009), s. 633-640.

[Rytel W.] Viator a MojówKa, Boskie Serce Jezusa ratuj Ojczyznę nasza, „Rodzina Seraficka”, 6 (1920), s. 227-229.

[Rytel W.] Viator a MojówKa, Spraw, by żolnierz był rycerzem Maryi, „Rodzina Seraficka”, 6 (1920), s. 289-292.

[Rytel W.] Viator, Bohater kapłan - tercjarz, „Rodzina Seraficka”, 6 (1920), s. 272-274.

SAdowski M., Redemptoryści na drogach polskiej niepodległości, „Studia Redemptorystowskie”, 16 (1918), s. 253-254.

\title{
POLISH CAPUCHINS AND THE EVENTS OF 1920
}

\begin{abstract}
Capuchins were not indifferent to the events taking place in Poland in 1920, due to serious staff shortages and the need to provide ongoing pastoral service of the monastery churches they could not get involved on a larger scale. Wiator Rytel, who was a chaplain of military hospitals, showed the greatest activity, in addition, he organized tertiary sewing of underwear for the army, and collecting various victims and contributions, for which, among others, a sanitary train was purchased and equipped.
\end{abstract}

Keywords: Poland; Capuchins; 1920 Year. 